\title{
PENERIMAAN WAGYU SEBAGAI SHOKU BUNKA JEPANG DI INDONESIA
}

\author{
Maharani Patria Ratna \\ Fakultas Ilmu Budaya, Universitas Diponegoro, Jl. Prof. Soedarto, SH, Kampus Undip \\ Tembalang, Semarang, Indonesia 50275 \\ Email: maharanipr_yellow@yahoo.co.id
}

\begin{abstract}
Wagyu is popular for its quality and its delicious taste. Nowadays wagyu has became a trademark for the best quality of beef. Wagyu is originally from Japan that now has spread to all over the world. 13 years ago, Indonesian government has banned the import of wagyu. But now the ban has been revoked. As a result some of indonesian people are still not familiar with the term of "wagyu". The purpose of this study are to know whether wagyu has been received as one of Japanese food or not and also the reasons behind it. This study is done by searching some references from trusted sources to answer those questions. The results of this study are wagyu has been well received by the people of Indonesia. The reasons are wagyu is already certified as halal food by MUI, now that in Indonesia there are many local breedres that produce local wagyu, and also recently there are many Indonesian food recipes that uses wagyu as its main ingredient.
\end{abstract}

Keywords: wagy; cow; shoku bunka; Japanese food; bred

\section{Pendahuluam}

Belakangan ini, wagyu menjadi primadona di antara beberapa jenis daging sapi yang disajikan di restoran. Wagyu sendiri sebenarnya berasal dari kata $w a$ (和) 'Jepang' dan gyu (牛) 'sapi'. Secara harfiah dapat dipahami bahwa wagyu adalah '(daging) sapi Jepang'. (Wakan) Wagyu yang saat ini dianggap sebagai daging sapi dengan kualitas terbaik biasanya dibanderol dengan harga mahal di restoran. Pada tahun 2017, situs detik.com menyebutkan bahwa di Indonesia, wagyu mentah dibanderol dengan harga $\mathrm{Rp}$. $800.000 / \mathrm{kg}$, sedangkan wagyu masak seharga Rp.200.000 per dua ratus kilogram.

Gambar 1. Daging wagyu

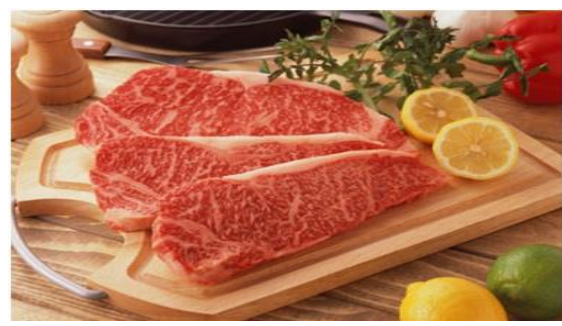

Sumber: j-cul.com 
Populernya wagyu belakangan ini telah mendorong lahirnya beberapa penelitian mengenai wagyu. Salah satunya adalah penelitian yang dilakukan oleh Andini dan Swacita (2014) serta Rosliana, dkk (2017). Andini dan Swacita (2014) membahas mengenai perbandingan kualitas daging sapi wagyu dan daging sapi Bali dengan hasil penelitian bahwa kadar protein dan kadar air wagyu lebih rendah daripada daging sapi Bali, sebaliknya kadar lemak dan kadar karbohidrat daging wagyu lebih tinggi daripada daging sapi Bali. Sedangkan Rosliana (2017) membahas mengenai sejarah dan warna budaya makanan atau shoku bunka (食文化) di Jepang. Hasil dari penelitian tersebut adalah bahwa sejarah munculnya shoku bunka dipengaruhi oleh masuknya budaya asing ke Jepang dan warna budaya tercermin dari cara orang Jepang memilih bahan dasar makanan, cara pengolahan, dan cara penyajian.

Berbeda dengan penelitian sebelumnya, penelitian ini memfokuskan kepada bagaimana penerimaan Wagyu sebagai shoku bunka baru di Indonesia serta latar belakang apa yang menurut peneliti menjadi faktor dalam penerimaan tersebut. Kedua masalah di atas patut untuk diteliti mengingat Wagyu merupakan jenis daging sapi asli Jepang yang mulai masuk ke Indonesia. Masyarakat Indonesia yang sebagian besar masyarakatnya menganut agama Islam sendiri dikenal selektif dalam memilih makanan, terutama terhadap makanan-makanan yang dilarang oleh agama. Tujuan penelitian ini adalah untuk mendeskripsikan bagaimana penerimaan shoku bunka Wagyu di Indonesia serta mendeskripsikan beberapa faktor yang melatarbelakangi hal tersebut. Dengan mengetahui hal-hal tersebut diharapkan bahwa penelitian ini dapat memberikan budaya mengenai Wagyu di Indonesia

\section{Metode Penelitian}

Metode yang digunakan dalam penelitian ini adalah deskriptif kualitatif. Deskriptif berarti bersifat menggambarkan apa adanya (KBBI, 1995). Sedangkan Strauss dan Corbin (1998: 10) mendefinisikan penelitian kualitatif sebagai penelitian yang tidak bermuara pada hasil statistik atau angka. Dengan demikian, secara sederhana, metode penelitian deskriptif kualitatif dapat dipahami sebagai metode penelitian yang menggambarkan objek 
dengan apa adanya dan tidak bermuara pada hasil statistik atau angka.

Untuk melakukan penelitian ini, dilakukan tiga tahapan, yakni tahap pengumpulan referensi, tahap analisis, dan tahap penyajian hasil. Sebagai upaya untuk mengumpulkan referensi, peneliti mengkaji beberapa sumber terpercaya seperti karya ilmiah, artikel koran, jurnal, dan sebagainya. Sumber-sumber tersebut diperoleh melalui beberapa disiplin ilmu. Selain itu, hal tersebut dilakukan agar penelitian ini memiliki jangkauan luas, sehingga dapat menghimpun deskripsi yang sesuai dengan tujuan dilakukannya penelitian ini. Setelah mengumpulkan referensi, maka dilakukan tahap selanjutnya, yakni tahap analisis.

Dengan mengacu kepada beberapa sumber yang telah disebutkan di atas, peneliti menganalisis hubungan sebab akibat yang muncul. Hubungan sebab diperoleh dari berbagai referensi sebagai dasar, sedangkan hubungan akibat diperoleh melalui analisis referensi dan fakta. Hasil yang dicapai dalam penelitian ini akan disajikan dalam bentuk deskripsi berdasarkan fakta yang disertai argumen. Melalui proses di atas, diharapkan tujuan dalam penelitian ini dapat tercapai. Sehingga diperoleh suatu pemahaman sederhana berdasarkan referensi, argumen, dan analisis .

\section{Hasil dan Pembahasan}

\subsection{Sejarah Wagyu}

Seperti yang telah disebutkan dalam uraian di atas, Wagyu sebenarya bukan merupakan nama ras sapi tertentu, melainkan secara harfiah berarti 'sapi Jepang'. Namun tentu saja tidak semua sapi Jepang disebut dengan Wagyu, hanya sapi yang memiliki karakterteristik tertentu yang dapat disebut dengan Wagyu. Pada pemerintahan ${ }^{1}$ Shogun tahun 1635 - 1838, dikeluarkan perintah untuk menutup seluruh peternakan di Jepang serta melarang masyarakatnya untuk memakan hewan ternak berkaki empat. Hal tersebut didukung dengan kuatnya pengaruh agama Buddha pada zaman tersebut di mana para pendeta Buddha melarang pengikutnya untuk memakan daging sapi. Selain itu, mengingat makanan pokok Jepang adalah nasi, maka pemerintah memutuskan untuk memperluas lahan pertanian dan menutup peternakan, sehingga hewan-hewan ternak pada masa tersebut-termasuk sapi

\footnotetext{
${ }^{1}$ Shogun: Pemerintahan militer
} 
Wagyu-digunakan sebagai hewan yang diperbantukan untuk proses pembajakan sawah

Selain membajak sawah, sapi Wagyu dahulu juga digunakan untuk menarik alat transportasi. Sapi Wagyu dipilih karena memiliki daya tahan fisik yang baik sehingga dianggap sangat cocok untuk ternak pekerja. Daya tahan fisik yang baik pada Wagyu berasal dari sel lemak dalam ototnya yang dipercaya tersebar merata pada permukaan dagingnya. Seiring dengan perkembangan zaman yang disertai dengan kemajuan teknologi, sapi Wagyu tidak lagi dijadikan ternak pekerja. Namun cara menernak sapi Wagyu yang membuatnya memiliki daya tahan fisik yang baik tetap dipertahankan hingga sekarang.

Oleh karena itu, sapi Wagyu sekarang ini diternak dengan tujuan yang berbeda dengan dahulu. Sapi Wagyu yang dahulu digunakan sebagai ternak pekerja, kini posisinya telah digantikan oleh alat-alat modern. Sapi Wagyu kini diternak dengan tujuan untuk dijadikan bahan makanan. Tidak hanya sekedar bahan makanan biasa, melainkan bahan makanan berupa daging sapi kualitas tinggi. Hal tersebut mengingat sel lemak dalam otot sapi Wagyu tersebar merata sehingga lezat untuk dikonsumsi.

\subsection{Penerimaan Wagyu di Indonesia}

Masyarakat Indonesia pada umumnya sudah cukup familiar dengan beberapa masakan Jepang, seperti sushi, ramen, onigiri, dll. Kepopuleran masakan Jepang dapat dibuktikan dengan adanya berbagai restoran, rumah makan, bahkan jajanan kaki lima khas Jepang yang sangat mudah ditemukan di kota-kota besar. Hal ini menandakan bahwa masakan Jepang sudah mendapat tempat tersendiri bagi masyarakat Indonesia. Lantas bagaimana dengan Wagyu? Bagi sebagian masyarakat Indonesia istilah "Wagyu" merupakan istilah yang baru mereka dengar. Hal ini dianggap wajar karena menurut majalah Tempo (2015), Wagyu baru saja mendapatkan lisensi impor dari pemerintah Indonesia setelah sebelumnya pemerintah melarang impor Wagyu selama 13 tahun.

Keputusan pemerintah ini dilatarbelakangi oleh isu penyakit kuku dan mulut pada sapi Jepang di tahun 2001. Dengan adanya isu tersebut, pemerintah Jepang mulai berbenah untuk memperbaiki kualitas sapinya. Hasilnya adalah pada 
tahun 2004 Jepang mulai melobi untuk kembali mengimpor Wagyu ke Indonesia, namun investigasi pemerintah Indonesia terhadap sapi Jepang baru bisa selesai pada 2014. Melalui uraian di atas dapat dipahami bahwa Wagyu dalam hal ini perlu untuk "memperkenalkan diri kembali" kepada masyarakat Indonesia. Cara yang ditempuh adalah dengan memasok Wagyu ke industri hotel, katering dan restoran yang dianggap merupakan konsumen utama daging premium seperti Wagyu.

Berbagai literatur dan artikel mengenai Wagyu mulai sering dimuat oleh media guna memberikan pengetahuan mengenai daging yang sempat dilarang masuk ke Indonesia tersebut. Perlahan masyarakat mulai mengenal dan merasa ingin tahu tentang bagaimana rasa Wagyu yang terkenal dengan marbling atau persebaran lemak yang merata. Setelah merambah industri-industri tersebut, perlahan-lahan permintaan Wagyu oleh konsumen mulai bertambah. Berbagai menu dengan olahan Wagyu mulai diminati. Apalagi dengan dikeluarkannya fatwa halal Wagyu oleh MUI pada tahun 2015.

\subsection{Faktor Penerimaan Wagyu di Indonesia}

Melalui uraian di atas dapat dipahami bahwa Wagyu dapat diterima dengan baik oleh masyarakat Indonesia. Beberapa faktor yang menyebabkan penulis menyatakan bahwa Wagyu dapat diterima oleh masyarakat Indonesia adalah sebagai berikut:

1. MUI telah menjatuhkan fatwa halal kepada Wagyu khususnya kepada Rumah Pemotongan Hewan (RPH) Zenkai Meat yang terletak di Kumamoto Jepang (Tribun, 2015). Dalam hal ini RPH tersebut menjamin bahwa sapi mendapatkan perlakuan yang sama dengan sapi wagyu pada umumnya, hanya saja sapi wagyu bersertfikat halal tidak diberikan sake seperti layaknya sapi wagyu yang lain, melainkan hanya air mineral.

Gambar 2. Sapi wagyu

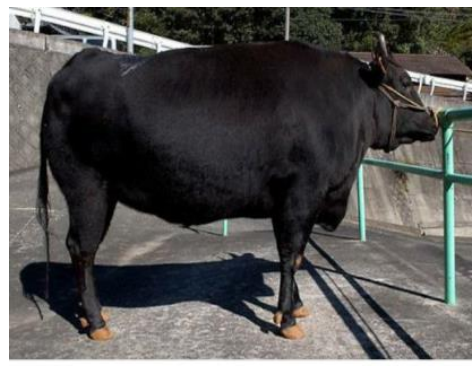

Sumber: www.sakadoci.com 
Selain itu, Lukmanul Hakim selaku direktur Lembaga Pengkajian Pangan, Obat, dan Kosmetik (LPPOM) MUI pun telah menjamin bahwa sertifikasi wagyu halal diberikan kepada RPH tersebut dengan memastikan cara pemotongan sapi hingga bagaimana sapi diolah. Di sisi lain, di Indonesia mulai diternak sapi calon wagyu. Sapi tersebut dikenal dengan sebutan wagyu lokal.

2. Munculnya RPH lokal yang memproduksi daging setara kualitas wagyu. Harian republika (2015) menyebutkan bahwa saat ini di Indonesia ada tiga perusahaan yang tengah menernak sapi wagyu, yakni PT. Santosa Agrindo, perusahaan sapi di Temanggung, dan perusahaan sapi di wilayah Kendal. Wagyu hasil ketiga perusahaan tersebut disebutkan dijamin halal karena dibiakkan dan disembelih dengan tata cara Islam. Dengan adanya RPH lokal yang menernak sapi wagyu, maka dapat dipahami bahwa kepopuleran wagyu di masyarakat membuat para peternak lokal berlomba-lomba untuk menghasilkan daging ternak dengan kualitas setara dengan wagyu asli Jepang. Wagyu halal ternyata tidak hanya diproduksi di Jepang dan di Indonesia saja, secara mengejutkan terdapat sebuah perusahaan yang juga mengantongi sertifikat halal, yakni Atlantic Beef Products, Inc. Perusahaan tersebut mendapatkan sertifikat halal dari The Islamic Food and Noutrition Council of Canada (IFCC).

3. Munculnya berbagai macam olahan wagyu di Indonesia. Berbagai media cetak untuk ibu rumah tangga di Indonesia mulai mencetak beberapa variasi resep pengolahan wagyu. Wagyu diolah sebagai bahan pokok masakan dengan bumbu khas Indonesia seperti tumis wagyu, nasi goreng wagyu, sate wagyu, dan sebagainya. Hal ini menjadi salah satu bukti bahwa masyarakat gemar dan antusias dengan kelezatan wagyu, sehingga terdorong untuk berkreasi mengolah wagyu dengan berbagai varian resep. Secara umum dapat dipahami bahwa masyarakat Indonesia menganggap bahwa wagyu dapat dijadikan bahan pokok makanan yang mudah untuk diolah seperti daging sapi lainnya.

Gambar 3. Sate Wagyu 


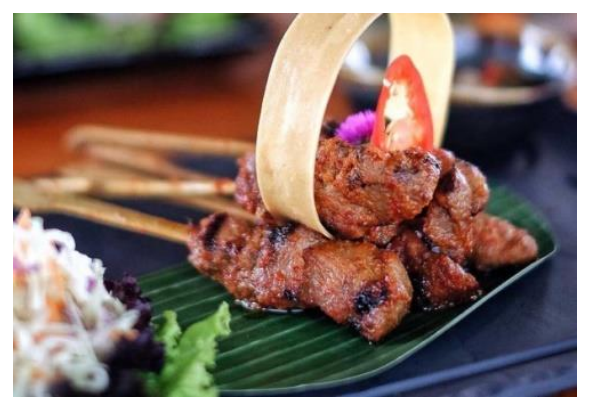

Sumber: www.qraved.com

\section{Simpulan}

Berdasarkan uraian di atas, maka dapat disumpulkan bahwa:

1. Wagyu dapat diterima dengan baik oleh masyarakat Indonesia

2. Penerimaan ini dipengaruhi oleh faktor wagyu telah mendapatkan sertfikasi halal oleh MUI, munculnya RPH lokal yang menernak sapi wagyu, serta munculnya banyak varian resep makanan untuk mengolah wagyu di media cetak.

\section{Daftar Pustaka}

Andini, Mita dan Ida Swacita. (2014). Kualitas Daging Sapi Wagyu Dan Daging Sapi Bali Yang Disimpan Pada Suhu $4{ }^{\circ} C$. Denpasar: Universitas Udayana
Halo Jepang. (2017). Daging Wagyu Halal Resmi Masuk Pasar Indonesia. Jakarta: The Daily Jakarta Shinbun.

Nakamoto, Jack. (2011). Jack's Japonica. Australia: Xlibris

Rosliana, Lina. (2017). Shoku Bunka: Warna Budaya Dan Tradisi Dalam Makanan Jepang. Semarang: Izumi

Straus, Anselm dan Juliet Corbin. (1998). Basics of qualitative research. California: Sage

Tempo. (2015). 13 Tahun Dilarang, Wagyu Jepang Masuk RI Lagi. Jakarta: PT. Temprint

Tribun News. (2015). MUI: Wagyu Daging Sapi Khas Jepang Halal. Jakarta: Tribun News

\section{Rujukan Elektronik:}

https://finance.detik.com/berita-ekonomibisnis/d-3655005/ini-dia-sapi-wagyu-asaljepang-harga-dagingnya-rp- $800000 \mathrm{~kg}$ (23/03/2018).

http://j-cul.com/daging-sapi-sehargajutaan-rupiah-di-jepang/(23/03/2018).

http://www.sakadoci.com/2016/06/inilahsapi-yang-paling-dimanja-sapi.html (23/03/2018).

\section{Daftar Kamus:}

Departemen Pendidikan Nasional. 1995. Kamus Besar Bahasa Indonesia. Jakarta: Balai Pustaka

Kamus Wakan edisi 1.6 
